\title{
Martin Heinrich Rathke (1793-1860) and his pouch and cyst
}

\author{
Ian K. H. Chun ${ }^{1} \cdot$ Naomi Ojumah $^{2} \cdot$ Marios Loukas $^{2} \cdot$ Rod J. Oskouian ${ }^{1}$ • \\ R. Shane Tubbs ${ }^{1}$
}

Received: 30 May 2017 / Accepted: 5 June 2017 / Published online: 23 June 2017

(C) Springer-Verlag GmbH Germany 2017

\section{Background}

Martin Heinrich Rathke (Fig. 1) was born in August 25, 1793, in the city of Danzig, Prussia, which is now Gdansk, Poland, and the child of George Heinrich and Catharina Elisabeth Streege. In 1814, Rathke attended the University of Göttingen to study medicine but soon moved to the University of Berlin in 1817, and in 1818 received his MD with his dissertation on the development of the ovaries in salamanders [5]. Rathke then returned to the city of Gdansk where he became a medical practitioner as well as an assistant professor of physics and physical geography. In his later work, he would meet Karl Burdach and Karl Baer who would be influential contemporaries in his continuing anatomical and embryological work. He began to work in the municipal hospital in 1825 where he became chief physician one year later in 1826. One of Rathke's most important works came during this time as he demonstrated the appearance of gill arches in animals. This was a significant finding in the understanding of homologous structures as well as the development of human embryos [11]. In 1829, he was offered a position as professor of Physiology and General Pathology at the University of Dorpat, which is now the University of Tartu in Estonia. During this time, Rathke left medical practice to pursue a research-based profession with an emphasis on comparative anatomy and embryology. During his tenure at Dorpat from

R. Shane Tubbs

shanet@seattlesciencefoundation.org

1 Seattle Science Foundation, 550 17th Ave, Suite 600, Seattle, WA, USA

2 Department of Anatomical Sciences, St. George's University, St. George's, Grenada
1829 to 1835 , Rathke would make discoveries in marine biology in the nearby Crimean and Black seas by naming new species as well as furthering knowledge of comparative anatomy [7]. He published work regarding many developmental processes in both vertebrates as well as aquatic animals, giving minute detail into embryological processes [6]. In 1835, Rathke received an invitation from the University of Konigsberg, now named Kaliningrad, to become a professor of anatomy and zoology.

\section{Rathke's pouch}

Through his extensive work, Rathke began to develop his theory of "backwards metamorphosis" which posited that some incipient structures would be reabsorbed or discarded to give rise to other structures. Using this idea, in 1838, Rathke published (Ueber die Entstehung der Glandula pituitaria) his discovery of "Rathke's pouch," a structure in developing embryos that gives rise to the anterior pituitary (adenohypophysis) [10] (Figs. 2 and 3). Rathke's pouch, also known as the hypophyseal diverticulum, is an ectodermal outpouching of the stomodeum (primitive oral cavity lined by ectoderm). Over several weeks, Rathke's pouch undergoes constriction at its base until it completely separates from the oral epithelium and nears its final position as the adenohypophysis. The transition from Rathke's pouch to the adenohypophysis involves the formation of the pars distalis from the rapidly proliferating anterior wall, the pars intermedia from the less active posterior wall, and the pars tuberalis from an upward outgrowth of the anterior wall [2].

\section{Rathke's cleft cyst}

During ontogeny, part of Rathke's pouch may remain, forming the anomaly known as Rathke's cleft cyst (RCC) 


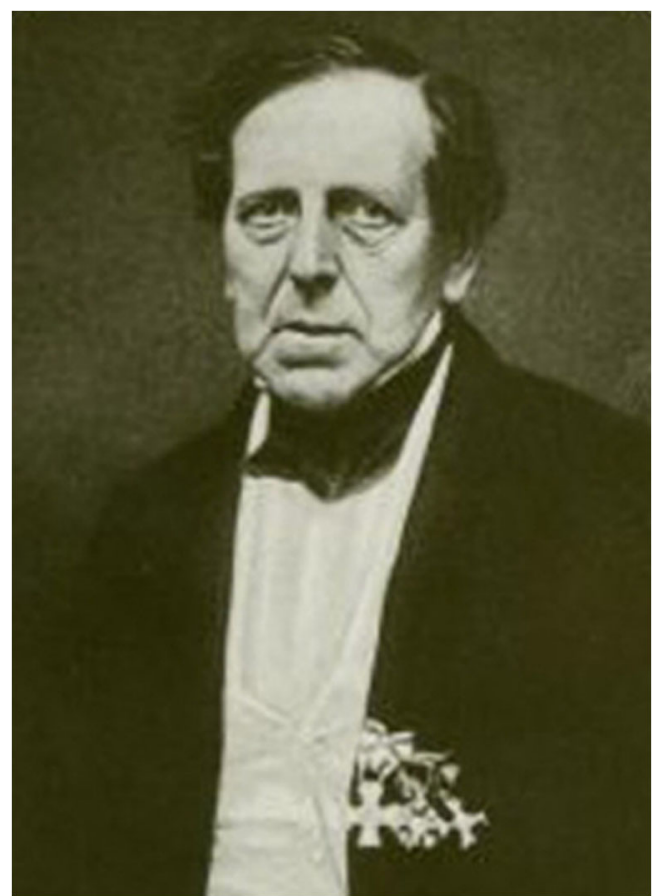

Fig. 1 Heinrich Rathke (1793-1860)

[1] (Fig. 4). These are fluid-filled cysts in the posterior portion of the anterior pituitary gland that are epithelium-lined. The most common theory about the origin of RCCs is that the cysts are derived from true remnants of the embryological Rathke's pouch [4]. The incidence of RCC in children and adolescents is unknown, but it is reported that an RCC was discovered in $1.7 \%$ of routine autopsies of people aged 10-29 years and in $13-22 \%$ of autopsies of older people. Although it is generally believed that a symptomatic RCC occurs rarely, the most

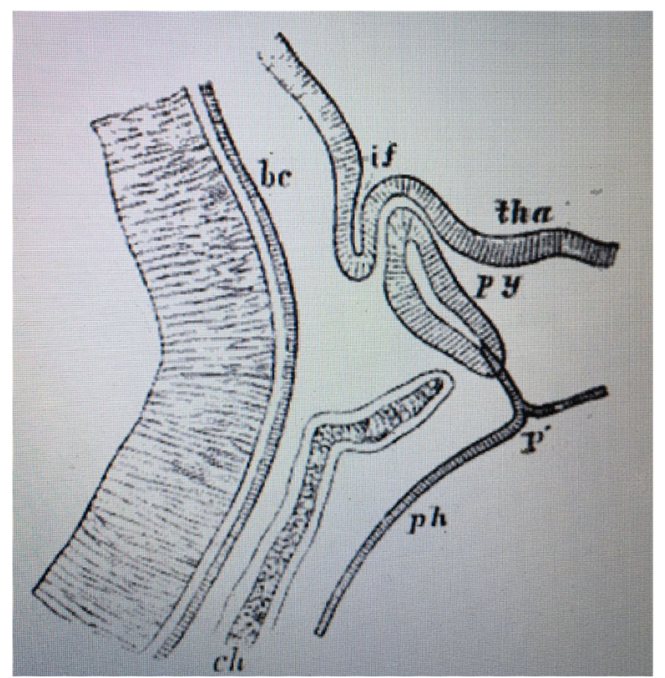

Fig. 2 Illustration of Rathke's pouch development in sagittal section. $c h$ notochord, $p y$ buccal pituitary involution, $p h$ pharynx, $p 1$ stalk of original communication with mouth, $b c$ sphenoidal part of cranial base, if infundibulum, and tha floor of diencephalon
Ueber die Entstehung der Glandula pituitaria. Von HEINRICH RATHKR.

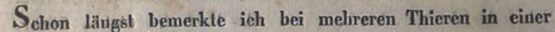
sehr frühen Zeit des Fruchtlebens, bei Säugethieren namentlieh geraume Zeit früher, als sich der Gaumen bildet, ganz hinten in der Mundhöhle, unterhalb der Grundfläche des Schädels eine keine unregelmässig rundliche Vertiefung, die der Schleimhaut des Mundes angehörte und offenbar eine dünnwandige Aussackung derselben war. Lange aber wusste ich sie nicht zu deuten, zumal da ich sie bei alteren Embryonen, wenn ich die Mundhöhle untersuchte, nicht mehr wiederfand. Endlich ward ich gewahe, dass diese Vertiefung den ersten Schritt zur Bildung des Hirnanhanges (Gland. pituitaria) bezeichnet. Bevor ich nun aber das weitere Verhalten derselben schildere, sehe ich mich genöthigt ein Paar Worte über den Schädel vorauszuschicken. Der Stern von der Chorda dorsalis reicht, wie es allen Anschein hat, vielleicht bei allen Wirbelthieren nur bis zwischen die beiden Knorpelkapseln, welche bei den mit einem Knochenskelett versehenen Thieren su den

Fig. 3 Title page of Rathke's 1838 publication Ueber die Entstehung der Glandula pituitaria. (Archiv für Anatomie, Physiologie und wissenschaftliche Medicin, Berlin, 1838: 482-485) on the pituitary gland

common clinical manifestations include headache, visual disturbance, and variable endocrine insufficiencies. Less frequent presentations include pituitary apoplexy, abscess formation, and meningitis [3].

There are several other pathologies derived from the Rathke's pouch. More rarely, the craniopharyngeal canal which is the pathway of the Rathke's pouch can also remain (after 6-7 weeks gestation), resulting in a persistent craniopharyngeal canal on MRI, which is associated with trans-sphenoidal meningoencephaloceles, ectopic pituitary tissue, sphenoid teratomas, and infrasellar

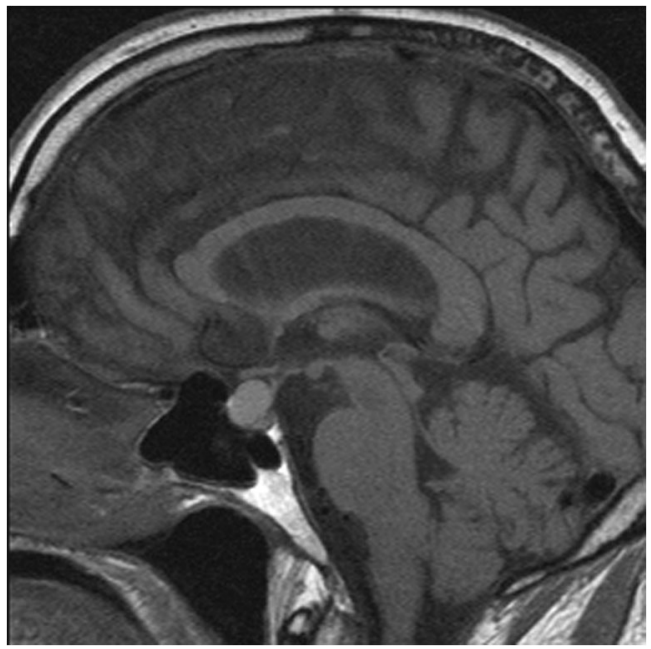

Fig. 4 T1-weighted, sagittal MRI noting a Rathke's pouch cyst within the sella turcica 
craniopharyngiomas [4]. Craniopharyngiomas are benign and suprasellar cystic masses perhaps are also derived from Rathke's pouch. Radiologically, unlike RCCs, craniopharyngiomas typically demonstrate calcification and approximately $90 \%$ have nodular, globular, or rim enhancement [4].

\section{Later life}

Rathke expanded the knowledge of comparative anatomy with publications such as his detailed work on Branchiostoma lanceolatum, which is now commonly used as a model organism for invertebrate development studies [8]. Rathke went on to make numerous discoveries in the field of comparative embryology producing nearly 125 publications until his abrupt death in September 15, 1860. One of his better known works "Developmental history of vertebrates" was posthumously published in 1861 and was fundamental in the development of the field of embryology [9].

\section{Conclusions}

Rathke was an early pioneer in the field of developmental biology through his findings of homologous structures between multiple organisms. He traced the similarities in the development of lungs and gills as well as determining the appearance of Wolffian ducts in all mammals and attributing the name to Carl Wolff who first saw the structure in chickens. Rathke was an influential biologist in his day and his contributions continue to shape our current knowledge.

\section{Compliance with ethical standards}

Conflict of interest The authors have no conflicts of interest.

\section{References}

1. Cho KH, Chang H, Yamamoto M, Abe H, Rodríguez-Vázquez JF, Murakami G, Katori Y (2013) Rathke's pouch remnant and its regression process in the prenatal period. Childs Nerv Syst 29: 761-769

2. Foulad A (2015) Pituitary gland anatomy. Medscape. http:// emedicine.medscape.com/article/1899167-overview

3. Lim HH, Yang SW (2010) Risk factor for pituitary dysfunction in children and adolescents with Rathke's cleft cysts. Korean J Pediatr 53:759-765

4. Naik VD (2013) Case report: a case of symptomatic Rathke's cyst. BMJ Case Rep 25:1-10

5. Rathke, Martin Heinrich. Complete dictionary of scientific biography. Encyclopedia.com. 16 May. 2017. http://www.encyclopedia. com

6. Rathke H (1833) Abhandlungen zur Bildungs- und EntwicklungsGeschichte der Menschen und der Thiere. W. Engelmann, Leipzig

7. Rathke H (1843) Beiträge zur fauna Norwegens Breslau und Bonn: für die Akademie in Bonn: Eduard Weber's Buchhandlng

8. Rathke H (1841) Bemerkungen über den Bau des Amphioxus lanceolatus, eines Fisches aus der Ordnung der Cyclostomas. W. Engelmann, Königsberg

9. Rathke H (1861) Entwickelungsgeschichte der Wirbelthiere. W. Engelmann, Leipzig

10. Rathke H (1838) Ueber die Entstehung der Glandula pituitaria. Arch Anat Physiol Sci Med 40:482-485

11. Rathke H (1828) Ueber das Daseyn von Kiemenandeutungen bey menschlichen Embryonen. John Wilson and Son, Boston 